This article was published in Analytica Chimica Acta, 858(1), 24-31, 2015

http:// dx.doi.org/10.1016/j.aca.2014.12.042

\title{
An analytical multi-residue approach for the determination of semi-volatile organic pollutants in pine needles
}

José Avelino Silva ${ }^{a}$, Nuno Ratola ${ }^{a, b, *}$, Sara Ramos ${ }^{a}$, Vera Homem a , Lúcia Santos ${ }^{\mathrm{a}}$, Arminda Alves ${ }^{\mathrm{a}}$

a LEPABE - Laboratory for Process Engineering, Environment, Biotechnology and Energy, Faculty of Engineering, University of Porto, Rua Dr. Roberto Frias, 4200465 Porto, Portugal

b Physics of the Earth, Regional Campus of International Excellence "Campus Mare Nostrum", University of Murcia, Edificio CIOyN, Campus de Espinardo, 30100 Murcia, Spain

\begin{abstract}
Vegetation (and pine needles in particular) has been widely used as an alternative to other conventional sampling devices to assess the atmospheric presence of semi-volatile organic contaminants (SVOCs). While most analytical procedures developed focus only on one or two chemical classes, this this work intends to establish a multi-component protocol to quantify brominated flameretardants (BFRs), polychlorinated biphenyls (PCBs), organochlorine pesticides (OCPs), polynuclear aromatic hydrocarbons (PAHs) and one class of contaminant of emerging concern, the synthetic musks fragrances (SMCs). Pine needles extracts were obtained by ultrasonic solvents extraction (USE), and different cleanup approaches using solid-phase extraction (SPE) employing combinations of sorbents and solvents as well as gel permeation chromatography (GPC) were tested. SPE with alumina followed by GCP yielded the best results, with average recoveries over $80 \%$.

The application of the method under field conditions was proven by the analysis of naturally contaminated samples from 3 sites of different potential exposure (remote, rural and urban). The total detected concentrations ranged from 0.45 to $0.87 \mathrm{ng} \mathrm{g}^{-1}$ dry weight (dw) for BFRs, 0.35 to $1.01 \mathrm{ng} \mathrm{g}^{-1}$ (dw) for PCBs, 0.36 to $12.2 \mathrm{ng} \mathrm{g}^{-1}(\mathrm{dw})$ for $\mathrm{HCB}, 245.7$ to $967.8 \mathrm{ngg}^{-1}$ (dw) for PAHs and 20.7 to $277.5 \mathrm{ng} \mathrm{g}^{-1}(\mathrm{dw})$ for SMCs.

This methodology is a viable approach for the simultaneous analysis of five different classes of atmospheric pollutants employing less analytical efforts. Moreover, to the author's best knowledge, this is also the first time vegetation
\end{abstract}


is employed in the detection of SMCs.

\section{Introduction}

The continuous release of hazardous chemicals into the atmosphere urges the development of comprehensive and expedite methodologies for their detection and subsequent study. Current emissions may not only comprise new contaminants, with scarce information about occurrence and impact on environmental health available, but also the so-called legacy persistent organic pollutants (POPs). These compounds belong to a variety of chemical classes that were widely used in the past, but have since been, restricted, banned or discontinued, yet they still remain in the environment due to their persistence [1]. Furthermore, their volatility, toxicity, bioaccumulation capacity and resistance to natural breakdown, either by biological, chemical or photochemical reactions, make them prone to long-range atmospheric transport (LRAT) [2] causing an environmental impact on areas far away from their points of emission. In 2004, the Stockholm Convention on Persistent Organic Pollutants (SCPOP) became effective, aiming to ban or restrict the use of POPs [2]. Examples include polychlorinated biphenyls (PCBs), brominated flame- retardants (BFRs), some organochlorine pesticides (OCPs) and, although not a part of the list but with similar properties, polycyclic aromatic hydrocarbons (PAHs). PCBs were used as cooling and dieletric fluids in transformers and capacitors and banned in 1979 in the USA [3] and 1985 in the EU [4]. BFRs, namely polybrominated diphenyl ethers (PBDEs) were widely incorporated as flame retardants in electrical appliances and furniture, but have now been restricted in several states of the USA [5] and in the EU [6]. Some organochlorine pesticides (OCPs) employed in crop protection and pest control, such as hexchlorobenzene (HCB), have also been banned globally under the SCPOP [2]. While BFRs, PCBs and OCPs are synthetic compounds and therefore exclusively of anthropogenic sources, PAHs derivenot only from human activities (combustion in traffic, industries and home heating) but also from natural processes associated with fossil fuels (forest fires, volcanic eruptions, etc.) [7]. The list of POPs is periodically reviewed and new contaminants can be added, once their effect on organisms, persistence and LRAT capacity is evaluated. Synthetic musk compounds (SMCs), widely incorporated in personal care and household products, are one of the "emerging" candidates. Used in rather high quantities on a daily basis, their bioaccumulative potential [8,9] and endocrine disrupting action [10,11] allied to their LRAT [12] make them a current issue of concern.

The implementation of atmospheric monitoring plans is essential to assess the properties and behavior of such contaminants. As opposed to other more onerous approaches, monitoring using vegetation avoids previous sampling site set-up and is arguably the best tool for the estimation of the atmospheric contamination 
levels at remote or poorly accessible locations [13]. Pine trees proved to be especially suitable, due to their widespread occurrence and the ability to retain lipophilic compounds on their needles, which can remain in the tree for several years [13].

Extraction is an essential step in analytical procedures involving plant matrices and should be able to recover the analytes completely, avoiding the co-extraction of unintended compounds at the same time. The most used extraction technique reported in literature is Soxhlet or Soxtec [14-16] extraction, which offers generally good recoveries, but requires rather large amounts of solvents and is time demanding. Ultrasonic solvent extraction (USE) $[14,17,18]$ and ultrasonic assisted enzymatic digestion (USAED) [19] have been employed as an alternative, using smaller amounts of solvent much shorter extraction times. Pressurized liquid extraction (PLE) [14,20,21] and supercritical fluid extraction (SFE) [22,23] are other alternatives, but require expensive equipment. A subsequent cleanup of the vegetation extracts for multicomponent analysis is often needed and is always challenging step, given the balance between cleanup efficiency and recovery. Solid-phase extraction (SPE) using cartridges or glass columns are broadly employed for pine needle extracts, with silica [24,25], Florisil $\mathbb{R}[21,26]$ and alumina [24,26] as the main sorbents. Gel permeation chromatography (GPC), a separation technique based on molecular size [27], is also used, individually [28] or combined with SPE [29].

Our workgroup has previous experience in the development and validation of analytical methodologies to evaluate the levels of PAHs, OCPs and PBDEs in pine needles $[13,26,30]$. The current study intends to establish an innovative multicomponent protocol to extract simultaneously four classes of more "traditional" compounds (BFRs, PCBs, PAHs and OCPs) and, for the first time, SMCs from pine needles. This approach will reduce the workload needed to obtain a comprehensive view of the atmospheric contamination and its deposition in vegetation matrices. To the authors' best knowledge, this is the first time SMCs can be included on a biomonitoring framework using vegetation.

\section{Experimental}

\subsection{Reagents and materials}

High-purity dichloromethane (DCM), n-hexane (Hex) and acetone were supplied by VWR BDH Prolabo (Leuven, Belgium). Florisil $\mathbb{R}$ (magnesium silicate, particle size $0.150-0.250 \mathrm{~mm}$ ), alumina (neutral aluminum oxide 90, particle size $0.063-0.200 \mathrm{~mm}$ ), silica (silica gel 60, particle size $0.062-0.200 \mathrm{~mm}$ ) and sodium sulphate were acquired from Merck (Darmstadt, Germany) and activated overnight at $450^{\circ} \mathrm{C}$. Deactivated alumina was prepared by adding $10 \%$ $(\mathrm{m} / \mathrm{m})$ of ultrapure water (Fluka Chromasolv, Steinheim, Germany) to the 
previously activated alumina and stabilized overnight. S-X3 Bio-Beads $\mathbb{R}$ were acquired from Bio-Rad (Amadora, Portugal).

Individual PBDE standards (congeners 28, 47, 85, 99, 100, 153, 154, 183) were bought as individual $50 \mathrm{mg} \mathrm{mL}^{-1}$ solutions in isooctanefromSigma-Aldrich (St. Louis, MI, USA). A mix of sixteen PAHs containing naphthalene (Naph), acenaphthylene (Acy), acenaphthene (Ace), fluorine (Fluo), phenanthrene (Phen), anthracene (Ānt), fluoranthene (Flt), pyrene (Pyr), benz(a) anthracene (BaA), chrysene (Chry), benzo(b) fluoranthene and benzo(k)fluoranthene $(\mathrm{BbF}+$ $\mathrm{BkF})$, benzo(a) pyrene $(\mathrm{BaP})$, indeno(1,2,3-cd) pyrene (IcdP), dibenzo( $\mathrm{a}, \mathrm{h})$ anthracene (DahA), and benzo(g,h,i) perylene (BghiP) at $2000 \mu \mathrm{g} / \mathrm{mL}$ in DCM/benzene (1:1), a PCB mix (congeners 28, 52, 101, 138, 153, 180, 209 as $10 \mu \mathrm{g} \mathrm{mL}^{-1}$ in isooctane) and PCB $30\left(10 \mu \mathrm{g} \mathrm{mL}^{-1}\right.$ in heptane) as well as musk xylene (MX, $100 \mu \mathrm{g} \mathrm{mL}^{-1}$ in acetonitrile) were also obtained from Sigma-Aldrich. Dr. Ehrenstorfer standards (Augsburg, Germany) supplied a mix of PCBs (congeners 77, 81, 105, 114, 118, 123, 126, 156, 157, 167, 169, 189, $10 \mu \mathrm{g} \mathrm{mL}-1$ in isooctane), a mix of deuterium labeled PAHs (d-PAHs), containing naphthalene-d8, acenaphthene-d10, phenanthrene-d10, chrysene$\mathrm{d} 12$ and perylene-d12, $10 \mu \mathrm{g} \mathrm{mL}^{-1}$ in hexane and the neat standards of musk ketone (MK), musk ambrette (MA), hexachlorobenzene (HCB) and anthracene-d10. Individual hexabromobenzene (HBB), pentabromotoluene (PBT) and pentabromoethylbenzene (PBEB) standards (each $50 \mu \mathrm{g} \mathrm{mL}^{-1}$ in toluene) and a mix of ${ }^{13} \mathrm{C} 12$ mass labelled PCB congeners ( ${ }^{13} \mathrm{C} 12$-PCBs) including congeners $28,52,101,118,138,153,180$, all at $5 \mu \mathrm{g} \mathrm{mL}^{-1}$ in nonane, were acquired from Wellington laboratories (Guelph, ON, Canada). LGC Standards provided neat standards of cashmeran $\mathbb{R}(\mathrm{DPMI})$, celestolide $\mathbb{R}$ (ADBI), traseolide $^{\mathbb{R}}(\mathrm{ATII})$, phantolide $\mathbb{R}(\mathrm{AHMI})$, tonalide ${ }^{\mathbb{R}}(\mathrm{AHTN})$, galaxolide $\mathbb{R}$ (HHCB) as well as standard solutions of musk moskene (MM) and musk tibetene (MT), both $10 \mu \mathrm{g} \mathrm{mL}^{-1}$ in cyclohexane. All standards and stock solutions were stored in the dark in amber glass vials at $20{ }^{\circ} \mathrm{C}$.

Helium (99.9\%) used in the GC-MS system and nitrogen (99.9\%) for solvent evaporation were supplied by Air Liquide (Maia, Portugal).

\subsection{Ultrasonic solvent extraction (USE)}

Five grams of pine needles were cut into $1 \mathrm{~cm}$ bits, spiked with $10 \mathrm{ng} \mathrm{g}^{-1}$ of BFRs, PCBs and HCB and $25 \mathrm{ng} \mathrm{g}^{-1}$ of PAHs and SMCs and the same amount of surrogate standards ( ${ }^{13} \mathrm{C} 12-\mathrm{PCBs}$ and d-PAHs), and extracted with $100 \mathrm{~mL}$ of Hex/DCM (1:1) in a $420 \mathrm{~W}$ ultrasonic bath (J.P. Selecta, Barcelona, Spain) for 30 min. After solvent cooling, extracts were transferred into pear-shaped flasks and 
evaporated to approximately $1 \mathrm{~mL}$ in a Büchi R-210 rotary evaporator (Flawil, Switzerland).

\subsection{Cleanup}

Solid phase extraction (SPE) was performed using gravity-fed glass columns packed with $5 \mathrm{~g}$ of Florisil $\mathbb{R}$, silica, alumina or deactivated alumina and topped with anhydride sodium sulphate. Prior to sample loading, the columns were conditioned with $50 \mathrm{~mL}$ Hex/DCM (1:1). After the sample was transferred into the column, elution was performed with another $50 \mathrm{~mL}$ of the same solvent mixture and collected into pear shape flasks for evaporation to near dryness in a rotary evaporator.

Gel permeation chromatography (GPC) was used as an additional cleanup step, following the procedure described by Thomas, et al. [31]. Glass columns equipped with PTFE stopcocks and glass caps were prepared using $6 \mathrm{~g}$ of BioBeads $\mathbb{R}$ S-X3 pre-expanded overnight in Hex/DCM (1:1). Samples were transferred with 3 washings into the GPC columns and eluted with $40 \mathrm{~mL}$ of Hex/DCM (1:1), of which the first $15 \mathrm{~mL}$ were discarded. Subsequently, the solvent was evaporated to near dryness by rotary evaporation and nitrogen blowdown and reconstituted in $100 \mu \mathrm{L}$ Hex.

\subsection{Chromatography}

The instrumental quantification of the samples was performed using two different methods. For BFRs, PCBs and HCB, a Varian GC-MS system (Palo Alto, CA, USA), equipped with a Varian 450-GC gas chromatograph, a CP-1177 split/splitless injector, a CP 8410 auto-sampler and a Varian 240-MS ion trap mass spectrometer operated in electron ionization mode $(70 \mathrm{eV})$ with a filament emission current of $50 \mathrm{~mA}$ was used. Chromatographic separation was carried out with an Agilent (Santa Clara, CA, USA) CP-Sil 8CB capillary column (50 m $0.25 \mathrm{~mm}$ I.D., $0.2 \mu \mathrm{m}$ film thickness) equipped with a fused silica deactivated retention gap $(5 \mathrm{~m} \times 0.25$ $\mathrm{mm}$ I.D.). Carrier gas was helium at $1 \mathrm{~mL} \mathrm{~min}^{-1}$. The GC oven temperature started at $110^{\circ} \mathrm{C}$ (hold for $1.5 \mathrm{~min}$ ) then was raised to $150^{\circ} \mathrm{C}$ at $20^{\circ} \mathrm{C} \mathrm{min}-1$, then to 220 ${ }^{\circ} \mathrm{C}$ at $5^{\circ} \mathrm{C} \mathrm{min}^{-1}$ (held for $17.5 \mathrm{~min}$ ) and finally to $300{ }^{\circ} \mathrm{C}$ at the same rate and held for $9 \mathrm{~min}$. Injection volume was $1 \mu \mathrm{L}$ in splitless mode with an injection port temperature of $300^{\circ} \mathrm{C}$. Temperatures of the transfer line, manifold and ion trap were $250{ }^{\circ} \mathrm{C}, 50^{\circ} \mathrm{C}$ and $250{ }^{\circ} \mathrm{C}$, respectively.

For PAHs and SMCs, a Varian 4000 GC/MS (Palo Alto, CA, USA) ion trap mass spectrometer also operated in electron ionization $(70 \mathrm{eV})$ and the same filament current, injector and auto-sampler types was used. Capillary column was an Agilent J\&W DB-5 (30 m $0.25 \mathrm{~mm}, 0.25 \mu \mathrm{m}$ film thickness) and helium was the 
carrier gas $\left(1 \mathrm{~mL} \mathrm{~min}^{-1}\right)$. The oven temperature program started at $60^{\circ} \mathrm{C}$ for $1 \mathrm{~min}$ and was then raised to $175^{\circ} \mathrm{C}$ at $6^{\circ} \mathrm{C} \mathrm{min}^{-1}$ (held for $11.11 \mathrm{~min}$ ) and then to 300 ${ }^{\circ} \mathrm{C}$ at $5.5^{\circ} \mathrm{C} \mathrm{min}^{-1}$ (held for $10 \mathrm{~min}$ ). The injector was set to $280{ }^{\circ} \mathrm{C}$ and the injection volume was also $1 \mu \mathrm{L}$ in splitless mode. Transfer line, manifold and ion trap temperatures were the same as above.

In both methods, acquisition was done using time-scheduled selected ion storage (SIS) using the retention time windows and ions shown in Table 1 (BFRs, PCBs and HCB) and Table 2 (PAHs and SMCs). System control, data acquisition and processing were done by Varian MS workstation software (v. 6.9.3). Identification of the target compounds was based on the retention times and the relative abundance of the monitored ions. Quantification was done using internal standards employing ${ }^{13} \mathrm{C} 12-\mathrm{PCB}$ and d-PAHs.

\subsection{Operative and storage procedures}

The risk of external contaminations is an important issue when leading with this kind of atmospheric pollutants. In particular, the properties and widespread use of SMCs constitute a potential input that needs to be reduced. Consequently, analysts avoided using scented personal care products throughout this study and switched gloves whenever handling different samples. Glassware was also subject to a special cleaning and decontamination procedure. After soaking in a phosphates free detergent solution (Derquim LM03, Panreac, Barcelona, Spain) and rinsing with distilled water and acetone, non-calibrated material was baked-out at $400{ }^{\circ} \mathrm{C}$ for at least one hour. Finally, the containers were rinsed with pure Hex before use.

Photodegradation of the light sensitive compounds was avoided using amber glassware whenever possible. Otherwise, aluminum foil covers were employed. Complete solvent evaporation was also prevented in order to reduce the losses of the target analytes to a minimum. External contaminations were assessed via laboratory blanks, included periodically with extractions. The concentration of the samples were corrected accordingly, whenever needed.

\subsection{Naturally contaminated samples}

In order to prove the effectiveness of the method in field conditions and the suitability of pine needles to capture SMCs, naturally contaminated needles were collected and analyzed. Being a preliminary assessment, it was decided not to engage in a broad, time-consuming and logistically more expensive sampling campaign, but rather have a few samples representing different exposure patterns (as a function of their location). Three sampling sites in mainland Portugal were chosen. The "Fóia" site is located in a remote mountainous range of 
the southern Algarve region of Portugal. Elevation was $838 \mathrm{~m}$ a.s.l. and annual precipitation was $700 \mathrm{~mm}$, with an average temperature of $16.8^{\circ} \mathrm{C}$ [32]. The "Benlhevai" sample was collected in the rural inner northern countryside at an elevation of $680 \mathrm{~m}$. Annual precipitation and temperature were $623 \mathrm{~mm}$ a.s.1. and $12.8^{\circ} \mathrm{C}$, respectively [32]. The sampling site designated as "Porto" is located in highly urbanized area in the city of Porto, with an elevation of $123 \mathrm{~m}$ a.s.l. and average temperature of $15.9{ }^{\circ} \mathrm{C}$. Annual accumulated rainfall was $935.3 \mathrm{~mm}$ [33].

Two-year-old needles were collected in one piece from $P$. pinaster species, from the outer bottom branches of the trees and then wrapped in solvent-rinsed aluminum foil, packed in polypropylene freezing bags and stored at $-20{ }^{\circ} \mathrm{C}$. Needle age was accurately identified by the small gaps that are visible in the branches between the shoots from every year. The position of the tree and branches was chosen to allow for the highest exposure to atmosphere (outer branches) but at the same allowing some protection against rainfall and convenient accessibility (bottom branches). Duplicates of each sample were extracted and analyzed together with a procedural blank. Samples collected in the "Porto" site were also used for the method development.

\subsection{Moisture content}

The moisture content of the pine needles was determined using a procedure described previously [30]. In brief, $5 \mathrm{~g}$ of fresh needles were dried at $80^{\circ} \mathrm{C}$ until constant weight. The mass difference corresponds to the amount of water.

\section{Results and discussion}

\subsection{Preliminary tests}

A GC/MS method for the simultaneous analysis of all target compounds was initially attempted using a $60 \mathrm{~m}$ CP Sil 8CB column. Different oven temperature programs (ranging from 60 to $300^{\circ} \mathrm{C}$ ), injector temperatures $\left(250-300{ }^{\circ} \mathrm{C}\right.$ ) and injection volumes ( 1 and $2 \mu \mathrm{L})$, filament emission currents (10,50 and $100 \mathrm{~mA})$ and selected ion storage time schemes were tested in order to achieve optimum chromatographic performance. After several efforts, it became clear that two separate GC/MS programs would deliver the best results and therefore one was developed for BFRs, PCBs and HCB and the other for PAHs and SMCs. At this stage, a $30 \mathrm{~m}$ DB-5 column was chosen for the separation of the latter set, as a slightly better performance was obtained, namely for the less volatile PAHs.

As mentioned previously, a thorough cleanup of matrices containing several coextractives such as chlorophylls, lipids, waxes and sugars is essential to obtain a good chromatographic performance. Different cleanup approaches and setups were found in literature and, among them, the ones by Thomas et al. [31] and 
by Hubert et al. [28] were chosen as the most promising ones for adaptation. Thomas et al. [31] used a two-step cleanup procedure employing silica gel/acid silica followed by GPC to quantify PCBs in vegetation extracts (grass and silage). An identical set-up was tested. $8 \mathrm{~g}$ of activated silica were packed together with 8 g of sulphuric acid impregnated silica $(2: 1 \mathrm{~m} / \mathrm{m})$ and samples were eluted with $150 \mathrm{~mL}$ of Hex. After solvent evaporation the samples were further subjected to a cleanup by GPC using $6 \mathrm{~g}$ of Bio-Beads $\mathbb{R}$ S-X3 and elution with Hex/DCM (1:1). For this, the relevant fractions $(15-50 \mathrm{~mL})$ were identified by an elution profile, collecting consecutive $5 \mathrm{~mL}$ fractions of the eluate. Low recoveries were obtained for PAHs ( $<29 \%)$ and SMCs $(<8 \%)$, as expected due to the degradation of these compounds in the acid medium. To overcome this, the fractionation of PAHs and SMCs from the other compounds was attempted, but with poor results.

Elution profiles of several combinations of sorbents (alumina, Florisil $\mathbb{R}$ and silica) and solvents (Hex DCM, Hex/DCM (1:1)) were established collecting $5 \mathrm{~mL}$ fractions of eluate but no effective separation was possible, as SMCs and PAHs overlapped with the other compounds. Thus, cleanup with acidimpregnated silica columns was abandoned but nevertheless GPC were tested alone. Hubert et al. [28] obtained good recoveries and chromatographic performance using this approach for PAHs in pine needles extracts. For this, the same columns containing $6 \mathrm{~g}$ of Bio-Beads $\mathbb{R}$ S-X3 and solvents mentioned above were used, but the extracts were passed through glass columns containing approximately

$0.5 \mathrm{~g} \mathrm{Na} 2 \mathrm{SO} 4$ beforehand, in order to remove water. The resulting extracts showed a slight coloration with no waxy deposits, but yielded poor chromatographic performance. Based on these preliminary tests, an optimization of a SPE cleanup methodology followed by GPC was considered necessary.

\subsection{SPE cleanup optimization}

In order to potentiate the best results for the considerable number of target compounds analyzed, the performances of 3 sorbents (alumina, Florisil $\mathbb{R}$ and silica), previously activated overnight at $450^{\circ} \mathrm{C}$ were compared using glass columns followed by GPC. The amounts of solvents required were established by elution profiles, collecting consecutive $5 \mathrm{~mL}$ fractions. Ratola et al.[14] had already tested these three different sorbents for the cleanup of extracts of pine needles and concluded that alumina was the most suitable. However, these tests were only for PAHs and for a different pine species (P. pinea) and therefore further testing had to be made to include the other target compounds.

The eluent of the silica assay turned into a viscous green extract after solvent evaporation and was not amenable for GC/MS analysis and therefore discarded as 
a possible sorbent. Florisil $\mathbb{R}$ rendered low recoveries, on average below $30 \%$, and low reproducibility with RSD occasionally exceeding 100\% (data not shown). Alumina, on the other hand, showed the best performance, with high recoveries and good reproducibility as can be seen in Fig. 1. Except for the most volatile compounds (BDE 28, DPMI, Naph) and PBEB, recoveries were above 70\% and repeatability with RSDs generally below $10 \%$. Average recoveries \pm average RSD were $88 \pm 2 \%$ for BFRs, $94 \pm 4 \%$ for PCBs, $80 \pm 8 \%$ for PAHs and $90 \pm 3 \%$ for SMCs.

As sorbent activity can play an important role in the cleanup process, a $10 \%$ water-deactivated alumina was tested. Recoveries were very similar to the ones of activated alumina: $84 \pm 7 \%$ for BFRs, $89 \pm 4 \%$ for PCBs, $75 \pm 7 \%$ for PAHs and 87 $\pm 8 \%$ for SMCs. However, repeatability expressed as RSD of triplicate extracts, was worse, especially for PBEB, HBB and nitromusks of the SMCs class. This is probably due to the difficulty in obtaining a completely homogenous deactivated sorbent but also due to increased matrix interferences, as chromatographic performance was not as good as with activated alumina. So, SPE with activated alumina followed by GPC was ultimately chosen as cleanup protocol.

\subsection{Method validation}

The method developed was validated regarding the linearity ranges, coefficients of determination, LODs and LOQs, recoveries and repeatabilities and the main results are detailed in Table 3. Due to the different levels of occurrence, two calibration levels were chosen. For BFRs, PCBs and HCB, which generally are present at lower levels, a good linear behavior was obtained between 4 and $600 \mu \mathrm{g} \mathrm{L}-1$, with coefficients of determination $\left(R^{2}\right)$ ranging from 0.991 to 0.999. Due to the lack of data regarding the occurrence of SMCs in vegetation, an identical calibration as for PAHs was chosen. The linearity range was from 10 to $1500 \mu \mathrm{g} \mathrm{L}{ }^{-1}$ with $R^{2}$ between 0.995 and 0.999 .

Repeatability and recovery were tested by spiking triplicate samples of needles at two concentration levels. For the lower level, $2 \mathrm{ngg}^{-1}$ of BFRs, PCBs and HCB and $5 \mathrm{ngg}^{-1}$ of PAHs and SMCs, whereas for the higher levels, $10 \mathrm{ng} \mathrm{g}^{-1}$ and $25 \mathrm{ng} \mathrm{g}^{-1}$, respectively. Overall, the recoveries were good, exceeding $70 \%$ when considering all chemical classes and both spiking levels. Exceptions were the most volatile compounds of BFRs, PAHs and SMCs (BDE 28, Naph and DPMI) which are more prone to losses during sample handling. Still, recoveries were above $40 \%$. Other compounds showing lower than average recoveries were PBEB, HBB and PCB 126. In these cases, the differences were more significant between both spiking levels, with lower values for the lower concentrations. One possible explanation is that these three compounds elute in a time frame that is more prone to coextraction of unintended chemicals. For all compounds, the repeatability (expressed as the RSD of triplicate extractions) was good, with most 
values below $10 \%$.

When dealing with pollutants at residual levels, low LODs and LOQs are essential to take valid conclusion about their occurrence. These parameters were estimated based on a signal-to-noise $(\mathrm{S} / \mathrm{N})$ ratio of 3 and 10, respectively. LODs and LOQs in the low $\mathrm{pg} \mathrm{g}^{-1}$ range were obtained for HCB (LOD $0.4 \mathrm{pg} \mathrm{g}^{-1}$, $\mathrm{dw}^{-1}$ LOQ $0.4 \mathrm{pg} \mathrm{g}^{-1}, \mathrm{dw}$ ), for PCBs (LODs $0.1-0.5 \mathrm{pg} \mathrm{g}^{-1}$, dw; LOQs $0.4-1.5 \mathrm{pg} \mathrm{g}^{-1}$, $\mathrm{dw}$ ), but also for BFRs (LODs $0.4-3.3 \mathrm{pg} \mathrm{g}^{-1}$, dw; LOQs 1.2-10.8 $\mathrm{pg} \mathrm{g}^{-1}, \mathrm{dw}$ ). For PAHs, LODs and LOQs were lower from for 2-4 ring PAHs (Naph-Chry; LODs 3.4-20.3 $\mathrm{pg} \mathrm{g}^{-1}$, dw; LOQs $11.4-65.2 \mathrm{pg} \mathrm{g}^{-1}$, dw) than for the 5-6 ring PAHs (BbF + BkF, BaP, DahA BghiP and IcdP; LODs 69.0-332.6 $\mathrm{pg} \mathrm{g}^{-1}$, dw; LOQs 196.7-1016.3 $\left.\mathrm{pgg}^{-1}, \mathrm{dw}\right)$. For SMCs, LODs ranged from $3.8 \mathrm{pgg}^{-1}(\mathrm{dw})$ for AHMI and $114.3 \mathrm{pgg}^{-1}$ (dw) for MM.

Taking into account the challenging matrix and multi-residue framework, results are very good, being recoveries and LODs comparable to others reported by authors who developed analytical approaches for only one or two chemical classes. For instance, Ratola et al. [26] employed a two-step SPE cleanup with alumina and Florisil ${ }^{\mathbb{R}}$ to quantify the same PBDEs studied here, but with the analysis performed by GC/NCI/MS, which is considered to have a higher sensitivity than the EI equipment [34]. Although the recoveries were slightly higher (from 99\% to 138\%), the reported LODs were in the same order of magnitude: $11-70 \mathrm{pg} \mathrm{g}^{-1}$, dw. Chen et al. [35] developed a method for the same PBDEs and a different pine species ( $P$. radiata) and achieved slightly higher LODs: 44-222 $\mathrm{pg} \mathrm{g}^{-1}$, dw. Lavin and Hageman [36] used P. radiata needles for the quantification of OCPs and PCBs, comparing PLE combined with GPC to selective PLE with no other cleanup and concluded that both methods perform similarly. Although HCB was not among the studied OCPs, for PCBs the recoveries (58-99\%, estimated from chart) and LODs (22-270 $\mathrm{pg} \mathrm{g}^{-1}$, fresh weight) were higher than those obtained with our method. PAHs have been extensively studied in pine needles and the LODs found in the current work are comparable to those reported by Gorshkov [37] and SchröterKermani et al. [25] for P. sylvestris and by Ratola et al. [14] for P. pinea. Being the first time that SMCs are analyzed in vegetation, no comparison could be done with a similar matrix. However, the LODs are similar to those reported for sediments [38], which ranged from 30 to $50 \mathrm{pg} \mathrm{g}^{-1}$.

This validation strategy confirmed the proposed method as a perfectly fit multiresidue approach to handle such a complicated matrix as pine needles. However, it was still important to assess its performance when applied to naturally contaminated samples. 


\subsection{Naturally contaminated samples}

The results of these assays are reported in Table 4, on a dry-weight basis in order to help the comparison between sites. The moisture levels for all samples of $P$. pinaster needles were very similar, ranging from 54 to $59 \%$.

While for legacy POPs and PAHs the occurrence in pine needles have been reported in literature, this is not the case for SMCs. Although the reduced number of samples does not favor the drawing of definitive conclusions, it is noteworthy that these chemicals show similar levels to PAHs and that being mainly linked to human presence and usage were found in higher concentrations in Fóia (remote) and Benlhevai (rural) and not in the urban area (Porto). Peck and Hornbuckle [39] detected an urban > suburban gradient, which is not seen in our case. Higher levels of SMCs in Benlhevai may be explained by the proximity of a landfill, where household residues are treated. The site in Fóia, on the other hand, may be prone to musks exposure by atmospheric transport. This possibility arises from its specific position overlooking the Algarve coast, a beachrelated densely tourist-populated region where personal care products employing SMCs (such as sun-block lotions) are extensively used. The Porto sample was collected in an area of intense vehicular traffic and more shielded from winds, due to nearby high-rise buildings. This may have diminished the needles' exposure to this kind of compounds. The distribution of individual SMCs was similar for all three sites, where no nitromusks were detected. This is probably due to the fact that these compounds were banned (MA, MT, MM), or at least restricted in their use (MX, MK) under the EU Directive 2012/21/EU [40]. In all three sites, HHCB and AHTN were predominant, in line with the $95 \%$ quota of these two musks in the EU market [41]. Another prevailing musk is DPMI, the most volatile, hence more prone to atmospheric transport.

Regarding PAHs, urban-stressed Porto shows the highest levels, with a total concentration of $967.8 \mathrm{ng} \mathrm{g}^{-1}(\mathrm{dw})$, nearly three times higher than Fóia and Benlhevai, which showed similar levels. Heavy traffic and industrial activity may be responsible for these values and land use gradient. The PAHs fingerprint was also distinct for each site, suggesting the contribution of different sources. For instance, in Fóia the levels of individual PAHs were Phen $>$ Flt $>$ Pyr while for Benlhevai it was Phen $>$ Flt $>$ BaA and for Porto Pyr $>$ Flt $>$ Chry. When compared to literature, levels are within the typically reported ranges and show a similar urban $>$ rural $>$ remote trend [24,25,42,43].

BFRs were detected in all sites at similar total levels (from 0.452 to 0.866 $\left.n g g^{-1}, d w\right)$, with a urban $>$ rural $>$ remote pattern. The BFRs detected were exclusively BDEs, as the new flame retardants (PBT, PBEB and HBB) were not found. In Fóia and Benlhevai, BDE 28 and BDE 99 were predominant, accounting for more than $70 \%$ of the BFRs incidence. Porto showed a slightly different BDE congener profile, with BDE 183 prevailing, but closely followed by BDEs 28 and 47. 
Kannan et al. [16] studied the levels of 8 BDEs and found total levels in the same range $\left(0.22-0.70 \mathrm{ng} \mathrm{g}^{-1}, \mathrm{dw}\right)$ and a decreasing trend between the city center and the outskirts.

Concentrations in the same order of magnitude $\left(0.353-1.014 \mathrm{ngg}^{-1}, \mathrm{dw}\right)$ were found for PCBs, replicating the same urban $>$ remote gradient found for BFRs. PCB 28 followed by PCB 52 were the most common, although Porto showed a greater variety of detected congeners, reflecting its urban fingerprint, as opposed to sites Fóia and Benlhevai, where only 3 PCBs were detected. The total levels of 22 PCBs found by Kannan et al. [16] were slightly higher (1.56-4.21 ng -1 , dw), while Romanic and Klincic [44] reported similar levels (0.15 and 9.91 ng $\mathrm{g}^{-1}$, dw), with a predominance of PCВ 28.

HCB, the only OCP analyzed, showed similar levels for Fóia and Benlhevai, and lower for Porto. Hellstrom [45] analyzed pine needles for organochlorine pesticides in Central and Northern Europe and found comparable incidences, between 0.16 and $10.10 \mathrm{ng} \mathrm{g}^{-1}(\mathrm{dw})$. Although no assessment between land uses was made, the author concluded that levels were quite uniform throughout Europe, which is in line with its enormous potential for LRAT.

Even with a reduced number of samples, this field study reinforced the applicability of the proposed multi-residue methodology and the suitability of pine needles to assess the incidence of SMCs. In order to confirm the tendencies or establish new ones, the design of sampling strategies with a wider geographical coverage and time span is strongly needed and should be implemented.

\section{Conclusions}

The innovative multi-residue methodology validated in this study and based on ultrasonic assisted extraction followed by a two-step cleanup employing activated alumina-SPE and GPC is a viable approach for the simultaneous analysis of BFRs, PCBs, PAHs, OCPs and SMCs in pine needles.

The results found analyzing naturally contaminated samples proved the ability of the method to respond when a field-based strategy is implemented. It was possible to quantify SMCs in vegetation for the first time (only polycyclic musks were detected) and find some preliminary geographical trends. The outcome of this study encourages the future application of this protocol to not only other compounds, but also to other environmental matrices.

\section{Acknowledgements}

Vera Homem would like to thank Fundação para a Ciência e a Tecnologia (FCT - Portugal) for the post-doctoral grant SFRH/BPD/ 76974/2011 co-funded by the 
QREN-POPH. This work has been partially funded by the European Union Seventh Framework Programme-Marie Curie COFUND (FP7/2007-2013) under UMU Incoming Mobility Programme ACTion (U-IMPACT) Grant Agreement 267143 and by funds through the Operational Programme for Competitiveness Factors - COMPETE and National Funds through FCT - Foundation for Science and Technology under the NORTE-07-0124-FEDER-000025, PEst-C/EQB/UI0511 and PTDC/AGR-CFL/102597/2008 projects.

\section{References}

[1] S. Harrad, Persistent Organic Pollutants, Wiley, Oxford, 2010.

[2] Stockholm Convention on Persistent Organic Pollutants (POPs), 2256 U.N.T.S. 119; 40 I.L.M. 532, 2001.

[3] Code of Federal Regulations, 44CF 31,514.

[4] The Council of the European Union, Council Directive 96/59/EC of

16 September 1996 on the disposal of polychlorinated biphenyls and polychlorinated terphenyls (PCB/PCT), Off. J. Eur. Union L243 (September) (1996) 31.

[5] National Conference of State Legislatures, http://www.ncsl.org/research/ environment-and-naturalresources/flame-retardants-in-consumer- products.aspx, (accessed 05.12.14).

[6] The Council of the European Union, Directive 2011/65/EU of the European Parliament and of the Council of 8 June 2011 on the restriction of the use of certain hazardous substances in electrical and electronic equipment, Off. J. Eur. Union L174 (June) (2011) 88.

[7] S. Boitsov, H.K.B. Jensen, J. Klungsøyr, Natural background and anthropogenic inputs of polycyclic aromatic hydrocarbons (PAH) in sediments of

South-Western Barents Sea, Mar. Environ. Res. 68 (2009) 236.

[8] D. Dietrich, B. Hitzfeld, Bioaccumulation and Ecotoxicity of Synthetic Musks in the Aquatic Environment, Springer, Heidelberg, Berlin, 2004.

[9] F. Balk, R.A. Ford, Environmental risk assessment for the polycyclic musks AHTN and HHCB in the EU, Toxicol. Lett. 111 (1999) 57.

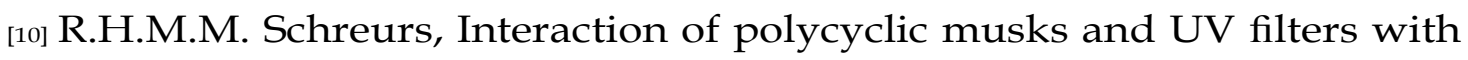
the estrogen receptor (ER), androgen receptor (AR), and progesterone receptor (PR) in reporter gene bioassays, Toxicol. Sci. 83 (2004) 264.

[11] H. Geyer, G. Rimkus, I. Scheunert, A. Kaune, K.-W. Schramm, A. Kettrup, M. Zeeman, D.G. Muir, L. Hansen, D. Mackay, Bioaccumulation - New Aspects and Developments, in: B. Beek (Ed.), Springer, Berlin Heidelberg, 2000. 
${ }_{[12]}$ Z. Xie, R. Ebinghaus, C. Temme, O. Heemken, W. Ruck, Air-sea exchange fluxes of synthetic polycyclic musks in the North Sea and the Arctic, Environ. Sci. Tech. 41 (2007) 5654.

[13] N. Ratola, V. Homem, J.A. Silva, R. Araújo, J.M. Amigo, L. Santos, A. Alves, Biomonitoring of pesticides by pine needles - chemical scoring, risk of exposure, levels and trends, Sci. Total Environ. 476-477 (2014) 114.

[14] N. Ratola, S. Lacorte, A. Alves, D. Barceló, Analysis of polycyclic aromatic hydrocarbons in pine needles by gas chromatography-mass spectrometry, J. Chromatogr. A 1114 (2006) 198.

[15] M. Malawska, I. Bojakowska, B. Wiłkomirski, Polycyclic aromatic hydrocarbons (PAHs) in peat and plants from selected peat-bogs in the northeast of Poland,

J. Plant Nutr. Soil Sci. 165 (2002) 686.

${ }^{[16]}$ N. Kannan, S.H. Hong, U.H. Yim, W.J. Shim, Biomonitoring background levels of PCBs and PBDEs in Seoul metropolitan atmosphere for possible health effects,

J. Toxicol. Environ. Health Sci. 1 (2009) 109.

[17] T.A. Tomashuk, T.M. Truong, M. Mantha, A.E. McGowin, Atmospheric polycyclic aromatic hydrocarbon profiles and sources in pine needles and particulate matter in Dayton Ohio, USA, Atmos. Environ. 51 (2012) 196.

[18] S. Sinkkonen, H. Raitio, J. Paasivirta, T. Rantio, M. Lahtiperä, R. Mäkelä, Concentrations of persistent organochlorine compounds in spruce needles from Western Finland, Chemosphere 30 (1995) 1415.

[19] G. Vale, R. Rial-Otero, A. Mota, L. Fonseca, J.L. Capelo, Ultrasonicassisted enzymatic digestion (USAED) for total elemental determination and elemental speciation: a tutorial, Talanta 75 (2008) 872.

${ }_{[20]}$ E. Lehndorff, L. Schwark, Biomonitoring airborne parent and alkylated three-ring PAHs in the Greater Cologne conurbation I: temporal accumulation patterns, Environ. Pollut. 157 (2009) 1323.

${ }_{[21]}$ T. Öberg, P. Peltola, Increased deposition of polychlorinated biphenyls (PCBs) under an AC high-voltage power line, Atmos. Environ. 43 (2009) 6168.

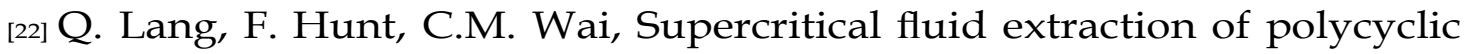
aromatic hydrocarbons from white pine (Pinus strobus) needles and its implications,

J. Environ. Monit. 2 (2000) 639.

[23] X.R. Zhu, H.K. Lee, Monitoring polychlorinated biphenyls in pine needles using supercritical fluid extraction as a pretreatment method, J. Chromatogr. A $976(2002) 393$.

[24] H.-M. Hwang, T.L. Wade, Aerial distribution, temperature-dependent seasonal variation, and sources of polycyclic aromatic hydrocarbons in pine needles from the Houston metropolitan area, Texas, USA, J. Environ. Sci. 
Health Part A 43 (2008) 1243.

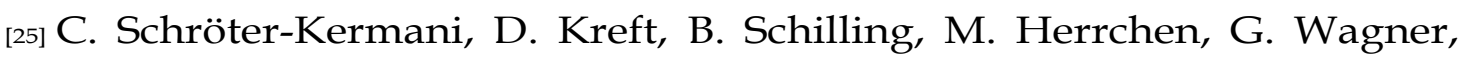
Polycyclic aromatic hydrocarbons in pine and spruce shoots temporal trends and spatial distribution, J. Environ. Monitor. 8 (2006) 806.

[26] N. Ratola, A. Alves, L. Santos, S. Lacorte, Pine needles as passive biosamplers to determine polybrominated diphenyl ethers, Chemosphere 85 (2011) 247.

[27] D.A. Skoog, D.M. West, S.R. Crouch, F.J. Holler, Fundamentals of Analytical Chemistry, Brooks/Cole, Belmont, CA, 2014.

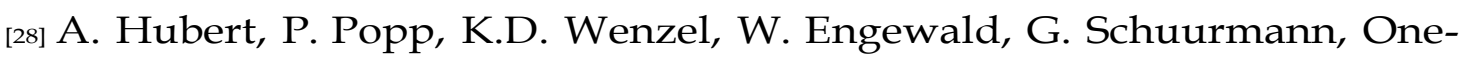
step cleanup for PAH residue analysis in plant matrices using size-exclusion chromatography, Anal. Bioanal. Chem. 376 (2003) 53.

[29] M.Y. Chun, Relationship between PAHs concentrations in ambient air and deposited on pine needles, Environ. Health Toxicol. 26 (2011) 1.

[30] N. Ratola, J.M. Amigo, M.S.N. Oliveira, R. Araújo, J.A. Silva, A. Alves, Differences between Pinus pinea and Pinus pinaster as bioindicators of polycyclic aromatic hydrocarbons, Environ. Exp. Bot. 72 (2011) 339.

[31] G.O. Thomas, A.J. Sweetman, C.A. Parker, H. Kreibich, K.C. Jones, Development and validation of methods for the trace determination of PCBs in biological matrices, Chemosphere 36 (1998) 2447.

[32] SNIRH (Sistema Nacional de Informação de Recursos Hídricos-Portugal), www.snirh.apambiente.pt/, (accessed 04.07.14).

[33] PORDATA (Base de Dados de Portugal Contemporâneo), http://www.pordata. pt/Portugal/Precipitacao+total-1070, (accessed 24.12.14).

[34] D. Barcelo, M. Petrovic, Sustainable Management of Sediment Resources, Elsevier, Amsterdam, Oxford, 2006.

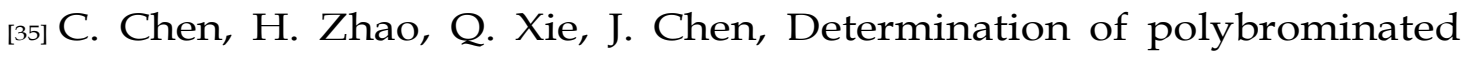
diphenyl ethers in pine needles using ultrasonic-assisted extraction and gas chromatography-negative chemical ionization-mass spectrometry, Se Pu 27 (2009) 59.

[36] K.S. Lavin, K.J. Hageman, Selective pressurised liquid extraction of halogenated pesticides and polychlorinated biphenyls from pine needles, J. Chromatogr. A 1258 (2012) 30.

[37] A.G. Gorshkov, Determination of polycyclic aromatic hydrocarbons in the needles of a Scotch pine (Pinus sylvestris L.), a biomonitor of atmospheric pollution, J. Anal. Chem. 63 (2008) 805.

[38] J.-S. Che, R.-P. Yu, Q.-J. Song, L.-P. Wang, S.-F. Wu, Determination of synthetic musks in the sediment of the Taihu lake by using accelerated solvent extraction (ASE) and GC/MS, Int. J. Environ. Anal. Chem. 91 (2011) 387.

[39] A.M. Peck, K.C. Hornbuckle, Synthetic musk fragrances in urban and rural 
air of Iowa and the Great Lakes, Atmos. Environ. 40 (2006) 6101.

[40] The Council of the European Union, Directives Commission Implementing Directive 2012/21/EU of 2 August 2012 amending, for the purpose of adaptation to technical progress, Annexes II and III to Council Directive $76 / 768 /$ EEC relating to cosmetic products, Off. J. Eur. Union L208 (August) (2012) 8.

[41] HERA Polycyclic musks AHTN (CAS 1506-02-1) and HHCB (CAS 1222-0505), Brussels, Belgium, 2004.

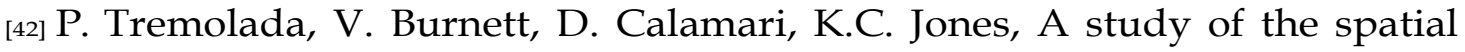
distribution of PCBs in the UK atmosphere using pine needles, Chemosphere 32 (1996) 2189.

[43] N. Ratola, J.M. Amigo, A. Alves, Levels and sources of PAHs in selected sites from Portugal: biomonitoring with Pinus pinea and Pinus pinaster needles, Arch. Environ. Con. Tox. 58 (2010) 631.

[44] S.H. Romanic, D. Klincic, Organochlorine compounds in pine needles from Croatia, Bull. Environ. Contam. Toxicol. 88 (2012) 838.

${ }_{[45]}$ A. Hellstrom, Distribution of some organochlorine compounds in pine needles from Central and Northern Europe, Environ. Pollut. 128 (2004) 29.
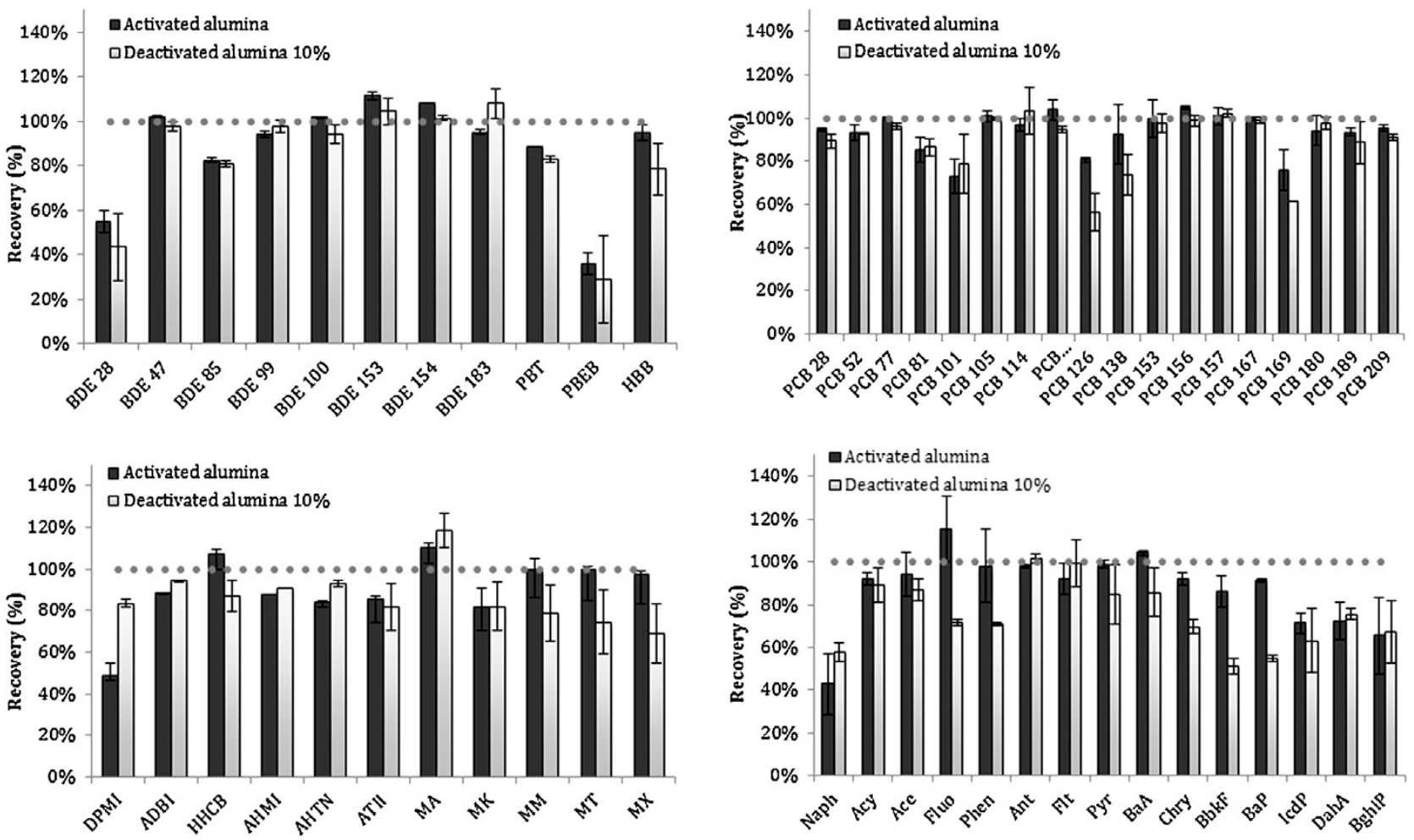

Fig. 1. Recoveries and standard deviation (as error bars) for USE extraction of spiked pine needles with $10 \mathrm{ng} \mathrm{g}^{-1}$ of BFRs and PCBs and $25 \mathrm{ng} \mathrm{g}^{-1}$ of PAHs and SMCs, using glass columns packed with $5 \mathrm{~g}$ of activated or $10 \%$ deactivated alumina. 


\section{Table 1}

GC-MS method parameters for BFRs, PCBs and HCB.

\begin{tabular}{|c|c|c|c|}
\hline $\begin{array}{l}\text { Time segment } \\
(\mathrm{min})\end{array}$ & $\begin{array}{l}\text { Retention time } \\
\text { (min) }\end{array}$ & Target compound & $\begin{array}{l}\text { lons } \\
(m / z)\end{array}$ \\
\hline \multirow[t]{4}{*}{$12.00-15.75$} & 12.37 & $\mathrm{HCB}$ & 284,286 \\
\hline & 13.04 & PCB 30 & $186,256,258$ \\
\hline & 15.11 & ${ }^{13} C_{12}-P C B 28$ & 268,270 \\
\hline & 15.12 & PCB 28 & $186,256,258$ \\
\hline \multirow[t]{2}{*}{$15.75-18.50$} & 16.21 & ${ }^{13} C_{12}-P C B 52$ & 302,306 \\
\hline & 16.33 & PCB 52 & $290,292,294$ \\
\hline \multirow[t]{25}{*}{$18.50-40.50$} & 19.60 & ${ }^{13} C_{12}-$ PCB 101 & 336,340 \\
\hline & 19.61 & PCB 101 & $324,326,328$ \\
\hline & 20.82 & PCB 77 & $290,292,294$ \\
\hline & 21.33 & PCB 81 & $290,292,294$ \\
\hline & 22.72 & ${ }^{13} C_{12}-$ PCB 118 & 336,340 \\
\hline & 22.72 & PCB $118+123$ & $324,326,328$ \\
\hline & 22.77 & BDE 28 & 246,248 \\
\hline & 23.04 & PBT & $407,408,486,489$ \\
\hline & 23.37 & PCB 114 & $324,326,328$ \\
\hline & 24.10 & ${ }^{13} C_{12}-$ PCB 153 & 372,374 \\
\hline & 24.13 & PCB 153 & 360,362 \\
\hline & 24.33 & PCB 105 & $324,326,328$ \\
\hline & 24.51 & PBEB & 500,504 \\
\hline & 26.03 & ${ }^{13} C_{12}-$ PCB 138 & 370,374 \\
\hline & 26.06 & PCB 138 & 360,362 \\
\hline & 26.73 & PCB 126 & $324,326,328$ \\
\hline & 28.45 & PCB 167 & 360,362 \\
\hline & 29.53 & HBB & 551, 554 \\
\hline & 30.53 & PCB 156 & $360,362,364$ \\
\hline & 31.11 & PCB 157 & $360,362,364$ \\
\hline & 32.43 & ${ }^{13} C_{12}-P C B 180$ & 405,410 \\
\hline & 32.45 & PCB 180 & $392,394,396$ \\
\hline & 32.51 & BDE 47 & 484,488 \\
\hline & 34.92 & PCB 169 & $360,362,364$ \\
\hline & 38.88 & PCB 189 & $394,396,398$ \\
\hline \multirow[t]{6}{*}{$40.50-51.00$} & 41.35 & BDE 100 & $404,406,408$ \\
\hline & 43.08 & BDE 99 & $404,406,408$ \\
\hline & 45.74 & PCB 209 & 496,501 \\
\hline & 45.74 & BDE 85 & $404,406,408$ \\
\hline & 47.10 & BDE 154 & $482,484,486$ \\
\hline & 48.77 & BDE 153 & $482,484,486$ \\
\hline $51.00-55.00$ & 53.26 & BDE 183 & $561,566,722,726$ \\
\hline
\end{tabular}

${ }^{13} \mathrm{C}_{12}$-labelled PCBs surrogates in italics well as PCB 30 used as internal standard. Quantification ions in bold. 
Table 2

GC-MS method parameters for PAHs and SMCs.

\begin{tabular}{|c|c|c|c|}
\hline $\begin{array}{l}\text { Time segment } \\
(\min )\end{array}$ & $\begin{array}{l}\text { Retention time } \\
(\mathrm{min})\end{array}$ & Target compound & $\begin{array}{l}\text { lons } \\
(m / z)\end{array}$ \\
\hline \multirow[t]{2}{*}{$9.00-15.50$} & 10.12 & Naph-ds & 136 \\
\hline & 10.51 & Naph & 128 \\
\hline \multirow[t]{5}{*}{$15.50-20.00$} & 16.38 & Acy & 152 \\
\hline & 16.57 & $A c e-d_{10}$ & 164 \\
\hline & 17.07 & Ace & 152,153 \\
\hline & 17.33 & DPMI & 163,191 \\
\hline & 19.10 & Fluo & 165,166 \\
\hline \multirow[t]{6}{*}{$20.00-23.80$} & 21.56 & ADBI & 173,229 \\
\hline & 22.54 & AHMI & 187,229 \\
\hline & 22.75 & Phen- $d_{10}$ & 188 \\
\hline & 23.52 & Phen & 178 \\
\hline & 23.07 & Ant-d 10 & 188 \\
\hline & 23.84 & Ant & 178 \\
\hline \multirow[t]{8}{*}{$23.80-30.00$} & 24.58 & MA & 253 \\
\hline & 25.19 & AT1I & 173,215 \\
\hline & 25.28 & НHCB & 213,243 \\
\hline & 25.37 & $\mathrm{MX}$ & 282 \\
\hline & 25.56 & AHTN & 159,243 \\
\hline & 26.16 & MM & 263 \\
\hline & 27.56 & MT & 251 \\
\hline & 29.00 & MK & 279 \\
\hline \multirow[t]{2}{*}{$30.00-40.00$} & 31.92 & Fluo & 200,202 \\
\hline & 32.68 & Pyr & 200,202 \\
\hline \multirow[t]{3}{*}{$40.00-46.00$} & 42.19 & $\mathrm{BaA}$ & 228,229 \\
\hline & 42.24 & Chry- $d_{12}$ & 240 \\
\hline & 43.33 & Chry & 228 \\
\hline \multirow[t]{3}{*}{$46.00-52.50$} & 48.52 & $\mathrm{BbF}+\mathrm{BkF}$ & 252 \\
\hline & 49.63 & $\mathrm{BaP}$ & 252 \\
\hline & 49.88 & Per- $d_{12}$ & 264 \\
\hline \multirow[t]{3}{*}{$52.50-57.00$} & 53.00 & IddP & 276 \\
\hline & 53.19 & DahA & 278,279 \\
\hline & 54.04 & BghiP & 276 \\
\hline
\end{tabular}

Deuterated PAHs surrogates in italics as well as Ant- $\mathrm{d}_{10}$ used as internal standard. Quantification ions in bold. 
Table 3

Method validation parameters: linearity range, coefficient of determination $\left(R^{2}\right)$, limit of detection (LOD), repeatability and recovery $(n=3)$

\begin{tabular}{|c|c|c|c|c|c|c|c|c|c|c|c|c|c|}
\hline & \multirow[t]{2}{*}{$\begin{array}{l}\text { LOD } \\
\left(\mathrm{pgg}^{-1} \mathrm{dw}\right)\end{array}$} & \multirow[t]{2}{*}{$\begin{array}{l}\text { LOQ } \\
\left(\operatorname{pgg}^{-1} \mathrm{dw}\right)\end{array}$} & \multicolumn{2}{|c|}{$\begin{array}{l}\text { Repeatability } \\
\text { (RSD \%) }\end{array}$} & \multicolumn{2}{|c|}{$\begin{array}{l}\text { Recovery } \\
(\%)\end{array}$} & & \multirow[t]{2}{*}{$\begin{array}{l}\text { LOD } \\
\left(\mathrm{pgg}^{-1} \mathrm{dw}\right)\end{array}$} & \multirow[t]{2}{*}{$\begin{array}{l}\text { LOQ } \\
\left(\mathrm{pgg}^{-1} \mathrm{dw}\right)\end{array}$} & \multicolumn{2}{|c|}{$\begin{array}{l}\text { Repeatability } \\
\text { (RSD \%) }\end{array}$} & \multicolumn{2}{|l|}{$\begin{array}{l}\text { Recovery } \\
(\%)\end{array}$} \\
\hline & & & $2 \mathrm{ngg}^{-1}$ & $10 \mathrm{ng} \mathrm{g}^{-1}$ & $2 \mathrm{ngg}^{-1}$ & $10 \mathrm{ng} \mathrm{g}^{-1}$ & & & & $5 \mathrm{ng} \mathrm{g}^{-1}$ & $25 \mathrm{ngg}^{-1}$ & $5 \mathrm{ngg}^{-1}$ & $25 \mathrm{ngg}^{-1}$ \\
\hline BFRs & & & & & & & SMCS & & & & & & \\
\hline BDE 28 & 0.4 & 1.2 & 13.4 & 5.1 & 53 & 55 & DPMI & 73.2 & 206.7 & 8.9 & 5.8 & 48 & 49 \\
\hline BDE 47 & 0.7 & 2.3 & 5.0 & 0.5 & 110 & 102 & ADBI & 4.6 & 15.1 & 1.7 & 0.2 & 85 & 89 \\
\hline BDE 85 & 0.8 & 2.8 & 0.9 & 1.1 & 110 & 83 & HHCB & 12.9 & 41.9 & 2.8 & 2.7 & 80 & 107 \\
\hline BDE 99 & 0.8 & 2.8 & 0.7 & 1.3 & 109 & 94 & AHMI & 3.8 & 12.5 & 2.2 & 0.1 & 84 & 88 \\
\hline BDE 100 & 0.7 & 2.3 & 2.6 & 0.4 & 109 & 102 & AHTN & 17.9 & 57.8 & 6.5 & 1.0 & 82 & 84 \\
\hline BDE 153 & 0.7 & 2.4 & 6.3 & 1.7 & 106 & 112 & ATII & 21.8 & 71.3 & 4.6 & 1.2 & 95 & 86 \\
\hline BDE 154 & 0.6 & 1.8 & 3.7 & 0.1 & 106 & 108 & MA & 5.0 & 11.0 & 4.3 & 20 & 99 & 111 \\
\hline BDE 183 & 1.1 & 3.6 & 6.3 & 0.9 & 103 & 95 & MK & 54.6 & 182.0 & 4.9 & 8.8 & 103 & 82 \\
\hline PBT & 0.9 & 2.9 & 6.6 & 0.1 & 109 & 89 & MM & 114.3 & 348.4 & 8.4 & 5.3 & 102 & 100 \\
\hline PBEB & 1.5 & 5.1 & 4.6 & 4.9 & 8 & 36 & MT & 48.8 & 162.6 & 6.2 & 1.7 & 104 & 100 \\
\hline HBB & 3.3 & 10.8 & 14.7 & 3.2 & 18 & 95 & MX & 53.0 & 176.7 & 1.9 & 1.6 & 107 & 97 \\
\hline PCBs & & & & & & & PAHs & & & & & & \\
\hline PCB 28 & 0.2 & 0.8 & 4.1 & 0.5 & 101 & 95 & Naph & 6.1 & 20.5 & 47.7 & 14.3 & 40 & 43 \\
\hline РСB 52 & 0.3 & 1.2 & 5.8 & 3.5 & 94 & 93 & Acy & 17.8 & 17.7 & 8.3 & 3.0 & 107 & 92 \\
\hline PCB 77 & 0.3 & 0.8 & 3.0 & 0.5 & 93 & 100 & Ace & 8.2 & 27.4 & 15.4 & 10.0 & 83 & 94 \\
\hline PCB 81 & 0.3 & 0.8 & 9.5 & 5.9 & 86 & 86 & Fluo & 4.7 & 15.6 & 7.1 & 15.2 & 113 & 115 \\
\hline РСB 101 & 0.4 & 1.2 & 7.7 & 7.7 & 90 & 73 & Phen & 5.6 & 18.5 & 8.5 & 17.2 & 80 & 98 \\
\hline PCB 105 & 0.3 & 1.1 & 4.2 & 2.3 & 98 & 101 & Ant & 4.3 & 14.2 & 2.2 & 0.5 & 63 & 98 \\
\hline PCB 114 & 0.3 & 1.0 & 0.5 & 3.2 & 98 & 97 & Flt & 3.4 & 11.4 & 5.2 & 7.0 & 58 & 92 \\
\hline PCB $118+123$ & 0.1 & 0.4 & 3.1 & 4.8 & 85 & 104 & Pyr & 5.1 & 17.1 & 4.2 & 1.9 & 104 & 99 \\
\hline РCB 126 & 0.3 & 1.2 & 10.1 & 1.2 & 35 & 81 & BaA & 20.3 & 65.2 & 1.0 & 1.2 & 106 & 104 \\
\hline РCB 138 & 0.4 & 1.4 & 4.3 & 13.7 & 93 & 92 & Chry & 12.9 & 40.5 & 4.0 & 2.9 & 91 & 92 \\
\hline РСB 153 & 0.4 & 1.4 & 0.7 & 8.9 & 99 & 100 & $\mathrm{BbF}+\mathrm{BkF}$ & 69.0 & 196.7 & 3.6 & 7.4 & 112 & 86 \\
\hline РCB 156 & 0.2 & 0.8 & 1.3 & 0.5 & 100 & 105 & $\mathrm{BaP}$ & 261.3 & 813.0 & 2.0 & 0.8 & 100 & 91 \\
\hline РСB 157 & 0.3 & 0.8 & 0.9 & 3.9 & 107 & 101 & IcdP & 304.9 & 1016.3 & 2.2 & 4.8 & 108 & 71 \\
\hline РСB 167 & 0.3 & 1.0 & 1.2 & 1.0 & 103 & 100 & DahA & 203.3 & 677.5 & 9.2 & 8.6 & 114 & 72 \\
\hline PCB 169 & 0.2 & 0.8 & 6.8 & 9.2 & 101 & 76 & BghiP & 332.6 & 871.1 & 4.3 & 17.8 & 121 & 66 \\
\hline РСB 180 & 0.5 & 1.5 & 1.9 & 7.0 & 103 & 94 & & & & & & & \\
\hline РСB 189 & 0.2 & 0.8 & 4.2 & 1.8 & 111 & 93 & $O C P$ & & & & & & \\
\hline РСB 209 & 0.2 & 0.8 & 4.7 & 1.3 & 113 & 96 & $\mathrm{HCB}$ & 0.4 & 1.3 & 5.3 & 4.6 & 79 & 85 \\
\hline
\end{tabular}


Table 4

Levels of BFRs, PCBs, SMCs, PAHs and HCB in naturally contaminated pine needle samples collected from three sites (Fóia, Benlhevai and Porto). Results in $\mathrm{ng}^{-1}$ dry weight \pm SD (mean of duplicate analysis).

\begin{tabular}{|c|c|c|c|c|c|c|c|}
\hline & Fóia & Benlhevai & Porto & & Fóia & Benlhevai & Porto \\
\hline BFRs & & & & SMCS & & & \\
\hline BDE 28 & $0.177 \pm 0.033$ & $0.289 \pm 0.011$ & $0.224 \pm 0.002$ & DPMI & $72.599 \pm 10.878$ & $58.870 \pm 1.933$ & $0.215 \pm 0.032$ \\
\hline BDE 47 & $0.018 \pm 0.001$ & $0.096 \pm 0.001$ & $0.176 \pm 0.015$ & ADBI & $0.294 \pm 0.015$ & $0.275 \pm 0.008$ & $0.093 \pm 0.010$ \\
\hline BDE 85 & nd & nd & nd & HHCB & $114.172 \pm 17.381$ & $216.364 \pm 2.805$ & $15.944 \pm .370$ \\
\hline BDE 99 & $0.191 \pm 0.026$ & $0.139 \pm 0.015$ & $0.072 \pm 0.009$ & AHMI & nd & nd & nd \\
\hline BDE 100 & nd & $0.024 \pm 0.001$ & $0.062 \pm 0.002$ & AHTN & $5.587 \pm 0.833$ & $2.028 \pm 0.147$ & $4.452 \pm 0.443$ \\
\hline BDE 153 & nd & nd & nd & ATII & $8.919 \pm 0.287$ & nd & nd \\
\hline BDE 154 & nd & nd & nd & MA & nd & nd & nd \\
\hline BDE 183 & $0.066 \pm 0.011$ & $0.056 \pm 0.009$ & $0.332 \pm 0.051$ & MK & nd & nd & nd \\
\hline 乏BDEs & 0.452 & 0.604 & 0.866 & MM & nd & nd & nd \\
\hline PBT & nd & nd & nd & MT & nd & nd & nd \\
\hline PBEB & nd & nd & nd & MX & nd & nd & nd \\
\hline HBB & nd & nd & nd & ESMCs & 201.6 & 277.5 & 20.7 \\
\hline PCAs & & & & PAHs & & & \\
\hline PCB 28 & $0.199 \pm 0.005$ & $0.208 \pm 0.019$ & $0.564 \pm 0.023$ & Naph & $6.373 \pm 1.036$ & $0.776 \pm 0.027$ & $1.019 \pm 0.139$ \\
\hline PCB 52 & $0.124 \pm 0.014$ & $0.205 \pm 0.050$ & $0.183 \pm 0.034$ & Acy & $3.193 \pm 0.231$ & $1.766 \pm 0.292$ & $14.799 \pm 2.434$ \\
\hline РCB 77 & nd & nd & nd & Ace & $26.682 \pm 2.751$ & $10.269 \pm 0.241$ & $25.583 \pm 0.703$ \\
\hline PCB 81 & nd & nd & nd & Fluo & $11.524 \pm 0.941$ & $25.367 \pm 1.626$ & $137.351 \pm 21.672$ \\
\hline PCB 101 & nd & nd & nd & Phen & $10.602 \pm 1.885$ & $112.367 \pm 1.067$ & $342.001 \pm 17.984$ \\
\hline PCB 105 & nd & $0.089 \pm 0.011$ & $0.053 \pm 0.005$ & Ant & $1.942 \pm 0.222$ & $2.290 \pm 0.003$ & $50.273 \pm 1.614$ \\
\hline PCB 114 & nd & nd & $0.025 \pm 0.001$ & Flt & $49.308 \pm 6.331$ & $52.789 \pm 0.245$ & $178.852 \pm 18.076$ \\
\hline PCB $118+123$ & nd & nd & nd & $\mathrm{Pyr}$ & $62.474 \pm 2.970$ & $29.786 \pm 0.103$ & $168.091 \pm 5.193$ \\
\hline PCB 126 & nd & nd & nd & BaA & $13.007 \pm 0.194$ & $36.169 \pm 0.685$ & $24.414 \pm 3.403$ \\
\hline PCB 138 & nd & nd & nd & Chry & $48.725 \pm 1.947$ & $9.343 \pm 0.071$ & $14.843 \pm 1.796$ \\
\hline PCB 153 & nd & nd & nd & $\mathrm{BbF}+\mathrm{BkF}$ & $0.587 \pm 0.024$ & $0.533 \pm 0.033$ & $2.144 \pm 1.247$ \\
\hline PCB 156 & nd & nd & nd & $\mathrm{BaP}$ & $0.407 \pm 0.023$ & $3.628 \pm 0.008$ & $0.614 \pm 0.083$ \\
\hline PCB 157 & nd & nd & nd & IdP & $8.542 \pm 0.430$ & $11.467 \pm 1.589$ & $5.872 \pm 0.726$ \\
\hline PCB 167 & nd & nd & nd & DahA & $1.619 \pm 0.745$ & $8.332 \pm 1.378$ & nd \\
\hline PCB 169 & nd & nd & nd & BghiP & $0.768 \pm 0.308$ & $1.031 \pm 0.156$ & $1.929 \pm 0.051$ \\
\hline PCB 180 & $0.030 \pm 0.001$ & nd & $0.135 \pm 0.003$ & EPAHs & 245.8 & 305.9 & 967.8 \\
\hline PCB 189 & nd & nd & nd & & & & \\
\hline PCB 209 & nd & nd & $0.054 \pm 0.007$ & $\alpha C P$ & & & \\
\hline ¿PCBs & 0.353 & 0.501 & 1.014 & HCB & $12.172 \pm 0.947$ & $10.050 \pm 0.434$ & $0.362 \pm 0.014$ \\
\hline
\end{tabular}

nd: not detected. 